\title{
External Environmental Factors Impacting on Access to Debt Finance by Small and Medium Enterprises in South Africa
}

\author{
Olawale Fatoki \\ Department of Business Management, Turfloop campus, University of \\ Limpopo, Limpopo Province, South Africa \\ Email: Olawale.fatoki@ul.ac.za
}

\section{Doi:10.5901/mjss.2014.v5n20p1013}

\begin{abstract}
Small and medium enterprises (SMEs) are critical to the reduction of the high rates of poverty and unemployment in South Africa. The failure rate of SMEs is very high. Access to debt finance is one of the major constraints to the survival of new SMEs in South Africa. Access to debt finance to by SMEs can be influenced by both borrower-specific (internal factors) and systemic factors (external factors). The objective of the study was to examine the external environmental factors that can impact on access to debt finance by SMEs in South Africa. The study evaluated how external factors such as the macro-economic environment, the legal system, crime and corruption can impact on access to debt finance by SMEs.
\end{abstract}

Keywords: SMEs, external environment, debt finance, small and medium enterprises, South Africa

\section{Introduction}

The South African economy is characterised by a low growth rate and a high rate of unemployment presently estimated at 25.2\% (Statistics South Africa, 2014). Small and medium enterprises (SMEs) are expected to be an important vehicle to address the challenges of job creation, sustainable economic growth, equitable distribution of income and the overall stimulation of economic development (Rogerson, 2008). According to a study by Asian Development Bank and the Organisation for Economic Cooperation and Development (2014), SMEs comprise the overwhelming majority of firms in almost all countries, and contribute to at least two thirds of total employment. SMEs drive economic growth through their contribution to innovation and productivity growth.

However, despite the noted contribution of SMEs as pointed out above, SMEs in South Africa suffer from a high failure rate. The survival rate of SMEs is relatively low and this is a global phenomenon. It is estimated that the failure rate of SMEs in South Africa is between 70 per cent and 80 per cent (Scheers, 2010), Cant and Wiid (2013). Various challenges and impediments cause the high failure rates of SMEs in South Africa. Access to finance represents one of the most significant challenges for SMEs. Herrington et al. (2009) note that access to finance is a major problem for the South African entrepreneur. Cosh et al. (2009) and the Organisation for Economic Cooperation and Development (2014) remark that an inherent problem that entrepreneurs face is their inability to attract external capital, given the lack of collateral and the presence of information asymmetry with investors. According to Demirguc-Kunt et al. (2006), the two primary sources of external finance for new SMEs are equity and debt. External equity in the form of venture capital or the stock exchange is usually not available for SMEs. Blumberg and Letterie (2008) agree that the lack of venture capital funds makes many SMEs dependent on debt financing. However, access to debt finance is limited for SMEs in South Africa (FinScope, 2010).

Beck (2007) argues that access to debt finance to by SMEs can be influenced by both borrower-specific (internal factors) and systemic factors (external factors). Haron et al. (2013) point out that borrower-specific factors include collateral and managerial competency. Furthermore, the scope for optimization that the lender will have in managing lending costs and risks can also be constrained by external or systemic factors. External factors include contractual and informational frameworks, macro-economic environment, social factors (crime and corruption), the regulatory environment and other characteristics of the business environment in which both the lender and borrower operate. These external environmental factors are not only outside the reach of lenders' actions, but neither can policy makers change them in the short-run. Beck (2007) adds that the weaker these external factors are, the less the manoeuvring room for credit supply optimisation. Given these constraints, there is the possibility that lenders will not maximise their lending opportunities to SMEs. Most of the studies on the factors impacting on access to debt finance by SMEs in South Africa have concentrated on borrower-specific factors (Mutezo, 2005), (Garwe and Fatoki, 2010). However, it is important to examine the external environmental factors that can also impact on access to debt finance by SMEs. 


\section{Objective of the Study}

SMEs in South Africa suffer from a high failure rate. Access to debt finance is one of the challenges faced by SMEs in South Africa. Understanding the factors that can impact on the access to debt finance by SMEs is critical to inclusive economic growth, poverty reduction and the creation of jobs in South Africa. The objective of the study is to examine the external environmental factors that can impact on access to debt finance by SMEs in South Africa.

\section{Literature Review}

\subsection{The external environment}

Ehlers and Lazenby (2011) point out that the external environment represents the variables in the environment that have a direct as well as an indirect influence on the organisation. The external environment is largely uncontrollable by the organisation. The external environment continuously changes. The external environment can play a very important role in the availability of finance to firms and the capital structure of SMEs. Barrios (2013) remark that lenders also consider economic conditions and the general climate, both within the industry and in other industries that could affect the business. The study focuses on four external variables. These are the macro-economic environment, the legal system, crime and corruption.

\subsubsection{The macro-economic environment}

Ehlers and Lazenby (2011) assert that economic forces ultimately result in prosperity or adversity, and have specific implications for an organisation or its management. Business organisations have to study the economic environment to identify changes and trends, and their strategic implications. Economic variables include the fiscal and monetary policies of the government, inflation, interest rates, and foreign exchange rates. These variables can influence the supply and demand for credit by SMEs. Correia et al. (2011) point out that the use of can either impact positively or negatively on the profitability of a firm. Debt is positive if the firm is able to earn a return on assets that is higher than the before-tax interest rate on debt. Positive leverage occurs when a firm operates under favourable conditions, when sales and profit margins are high and the firm is able to generate a good return on assets. Negative leverage happens when a firm faces difficult times, and sales and profit margins are low. This may affect the willingness of banks and trade creditors to grant credit to SMEs. Wehinger (2014) finds that economic recession has a negative effect on bank lending. Lee et al. (2013) find that one of the consequences of the 2008 financial crisis is that small innovative firms find it increasingly difficult to access external finance from commercial banks. Carbo-Valverde et al. (2012) concur that SMEs suffered from a significant credit crunch during the last financial crisis. The authors find that credit constrained SMEs depend on trade credit, but not bank loans, and that the intensity of this dependence increased during the financial crisis.

Barbosa and Moraes (2004) ascertain that a depressed economic condition is a characteristic associated with the likelihood of a firm's failure to repay its debt. During economic expansions, even marginal firms have ready access to debt capital. However, in recessions or downturns, the established firms that have both a record of past success and relatively good performance obtain a large percentage of new debt. This suggests that SMEs may find it difficult to pay back debt in a depressed economic environment. Baum and Caglavan (2008) note that as banks need to acquire costly information on borrowers before extending loans to new or existing customers, uncertainty about economic conditions (and the likelihood of loan default) would have clear effects on their lending strategies. Higher uncertainty will hinder managers' ability to accurately predict returns from available lending opportunities. When the macro-economic environment is tranquil, bank managers will be able to predict returns from each potential project more easily and channel funds towards projects with higher expected returns. However, when the economic environment is in turmoil, bank managers' ability to predict returns accurately will be hindered resulting in more conservative lending behaviour across all banks. Schwienbacher and Larralde (2010) point out that small business finance is highly and disproportionally affected by macroeconomic conditions. Market forecasts, stock market health, overall economy health, and monetary policy all have effects on small business finance.

The Organisation for Economic Cooperation and Development (2013) reports that South Africa's current economic environment is characterised by low growth rates, high unemployment, high inflation rates and volatile exchange rates. These factors can impact on the availability of debt finance to SMEs. According to the Wall Street Journal (2014), South Africa's economy shrank in the first quarter of 2014. There was a $0.6 \%$ annualized drop in the gross domestic product (GDP) of South Africa in the first three months of 2014. This was the worst since 2009, when the South African economy 
fell into recession. One of the causes is the drop in the GDP was the long strike in the mining sector especially platinum mines. In addition, consumer spending is weak. Weak economic conditions affect sales, revenues, market and growth potential of new SMEs. Weak economic conditions make it difficult for new SMEs to use debt positively and may negatively impact on the willingness of commercial banks to extend credit to new SMEs.

\subsubsection{The legal environment}

La Porta et al. (1997) (LLSV) set up the theoretical basis for the development of empirical studies in respect of the relationship between law and finance. LLSV argue that in the traditional finance theory of Modigliani and Miller (1958), securities (debt and equity) are recognized by their cash flows. According to Modigliani and Miller (1958) debt has a fixed promised stream of interest payments, whereas equity entitles the owner to receiving dividends.

LLSV (1997) argue that cash flow alone does not tell the whole story and that the defining feature of various securities is the rights that they bring to their owners. Shares typically give the owners the right to vote for the directors of the companies and shareholders receive dividends on their equity because they can vote out directors who do not pay them. Also, debt entitles creditors the power to repossess collateral when the company fails to make promised payments and creditors are thus paid because they have this power. Without these rights investors would not get paid and therefore firms would find it difficult to raise external finance. LLSV however dispute the view that securities are inherently characterized by some intrinsic rights and argue that this ignores the fact that these rights depend on the legal rule of the jurisdictions where the securities are issued. Law and the quality of its enforcement are potentially important determinants of what rights security holders have and how well these rights are protected. Since the protection of investors determines their readiness to finance firms, corporate finance may critically turn to these legal rules and their enforcement. Therefore, the differences in legal protection of investors might help explain why firms are financed differently in different countries.

LLSV (1998) assembled data covering legal rules pertaining to the rights of investors and the quality of enforcement of those rules (for creditors, these rules cover the respect for security of the loan, the ability to repossess collateral and the inability of management to seek protection from creditors voluntarily) in forty nine countries (South Africa included) that have publicly traded companies. They found that laws vary in a lot across countries, due in part to differences in their legal origin. Common law countries generally have the strongest and French civil law countries the weakest legal protection of investors and creditors. German and Scandinavian civil law countries are located in the middle implying that creditor protection in these countries is weaker than in British common law countries but stronger than in French civil law countries.

\subsubsection{Creditor protection in South Africa}

According to Djankov et al. (2007) creditor protection is measured by the creditor right index. The index ranges from 0 (weak creditor rights) to 4 (strong creditor rights). A score of one is assigned when each of the following rights of secured lenders are defined by laws and regulations. First, there are restrictions, such as creditor consent or minimum dividends, from a debtor to file for reorganization. Second, secured creditors are able to seize their collateral after reorganization petition is approved. This implies there is no automatic stay or asset freeze. Third, secured creditors are paid first out of the proceeds of liquidating bankrupt firm, as opposed to government or workers. Finally, management does not retain administration of its property pending the resolution of reorganization. Table 1 depicts the creditor right index of South Africa and some other developing and developed countries.

Table 1: Creditor rights index in South Africa and selected countries

\begin{tabular}{|l|c|}
\hline \multicolumn{1}{|c|}{ Country } & Creditor rights index \\
\hline South Africa & 3 \\
\hline Botswana & 3 \\
\hline Nigeria & 4 \\
\hline United Kingdom & 4 \\
\hline United States of America & 1 \\
\hline Cameroon & 0 \\
\hline France & 1 \\
\hline Sweden & 1 \\
\hline
\end{tabular}

Source: Adapted from Djankov et al. (2007). 
Table 1 shows that South Africa with an index of 3 has a relatively strong creditor protection. While the United States of America, France, Sweden and Cameroon with indexes ranging from 1 to 0 have very weak creditor protection. This implies that on paper creditors in South Africa enjoy high protection. Though creditor protection on paper is relatively strong, the efficiency of contract enforcement is quite low in South Africa. Standard and Poor's (2007) investigate debt recovery for creditors and the law of insolvency in South Africa. They find that South Africa is a friendly jurisdiction for secured creditors and perhaps the friendliest in Africa. However, in contrast to some of the most creditor-friendly jurisdictions around the world, secured creditors in South Africa do not have an unrestricted ability to foreclose on collateral outside of court proceedings, and such proceedings can be relatively slow and inefficient, with delays of enforcement of up to two years in some instances. Therefore, while debt recovery prospects for secured creditors are generally strong, such recoveries may be reduced by procedural delays and also the relatively high costs and fees of the enforcement process. Conclusively, South Africa's creditor right index is relatively strong, however, the long procedures, duration and cost it takes to register property, enforce contracts and close business upon bankruptcy may affect the availability of debt finance to new SMEs.

\subsubsection{Crime}

The United Nations Office on Drugs and Crime (2013) reports that crime is an important issue in South Africa. The country has halved its murder rate, but still remains one of the most violent countries in the world for homicide. Demombynes and Ozler (2005) agree that crime is among the most difficult of the many challenges facing South Africa in the post-apartheid era. According to the South African Police Service Crime Statistics (2014) while the incidences of virtually all major categories of crime has fallen during the past years, business related crime is on the increase. Robbery at non-residential premises (business) increased by $9.4 \%$ between 2009 and 2013 but reduced by $0.6 \%$ between 2012 and 2013.

Maas and Herrington (2006) and Isaacs and Freidrick (2007) point out that crime is one of the major factors that influence people negatively towards the creation of their own businesses in South Africa. The costs of crime are higher for SMEs than large firms and a major crime incident can hit a small firm very hard and leads to its failure to meet due obligations. Crime increases the cost of operations for a business and may negatively impact on its sustainability and success. Grant Thornton (2007) and Standard Bank and Fujistu Siemens Computers (2009) find that because of crime owners of SMEs are not aggressively pursuing avenues to grow their market shares and stay ahead of competitors. Rather they are focusing on operational matters. In addition, most SMEs in South Africa do not have insurance policies to protect their assets, both fixed and current. Chodokufa (2009) found that almost half of SMEs in South Africa do not have any insurance cover in the event of a crime. A high crime rate also reduces the value of properties that are used to collaterise loans. According to Linden and Rockoff (2008) in response to the crime risk, residents generally have two options; they can vote for anticrime policies, or they can vote with their feet. When individuals exercise the latter option, local response to crime will be observed in the housing market. The study finds a decrease in property values of 10 percent for a one standard deviation increase in property crime. Crime increases moral hazards after the granting of credit and can affect the ability of SMEs to repay credit. This may affect the willingness of banks and other creditors to extend credit to SMEs especially those that are located in high crime areas.

\subsubsection{Corruption}

Transparency International (2013) describes corruption as the abuse of entrusted power for private gain. Corruption in public and private establishments is growing in South Africa. The Corruption Perception Index (2013) published by Transparency International ranks South Africa $72^{\text {nd }}$ position out of 177 countries with a score of 42 out of 100 . Gaviria (2002), Kimuyu, (2007) and Athanasouli et al. (2012) find that corruption is negatively associated with firm growth. Gaviria (2002) examines the effect of corruption on firm performance and the types of firms that are likely to complain about corruption in Latin America. The study focused on three indices of firm performance; reported growth of sales, investment and employment. Results show that corruption has a noticeable effect on the economic outcome of firms in the sense that outcomes tend to be lower in firms where managers report that corruption is an obstacle to doing business than in firms where managers report otherwise. The effect of corruption on sales growth is positive and statistically significant. Several mechanisms can explain the adverse effect of corruption on firm performance. First, corruption raises operational costs, lowering competitiveness and ultimately lowering sales. Secondly, corruption prevents firms from entering profitable business, limiting the opportunities for growth and lowering sales, investment and employment. Finally corruption may cause firms to lose valuable human and financial resources, likewise lowering competitiveness. 
The United Nations Industrial Development Organisation (2007) argues that corruption has been found to distort fair competition and the rules of the free market economy, has a negative impact on quality of products and services, weakens the prospect of economic investment and undermines business ethics. Corruption is detrimental to all types of business but most especially SMEs. Corruption can be public or private. Public corruption involves government officials seeking personal gains in order to grant licenses, permits and tax incentives. Private corrupt interactions include embezzlement by employees, bribing and extortion by employees of larger companies in order to obtain contracts and corrupt bank officials approving loans that do not meet basic financial criteria and can therefore not be collected later.

Weill (2009) points out that the key argument that corruption should be expected to hamper bank lending is based on the law and finance theory pioneered by LLSV (1997). Legal institutions protecting banks and enforcing contracts are likely to encourage greater bank lending by increasing the willingness of banks to grant loans. In the case of borrower default, the bank may wish to force repayment, to grab collateral or even in some cases to take control of the borrower in case of a corporate loan. Therefore, the institutions that empower the bank to proceed to these actions exert an influence on its lending behaviour. As corruption adds to uncertainty for banks to enforce their claims against defaulting borrowers, it diminishes the willingness of banks to grant loans. Greater corruption adds to uncertainty of judicial decisions for banks, as they cannot count on the courts to enforce damages recoveries for losses or deficiency judgments against defaulting debtors, and consequently banks are expected to refrain from lending. Weill (2009) adds that corruption can also take place in lending through bribes given to bank officials to receive a loan. Ahmad (2013) argues that a form of corruption that can impact on bank credit is corruption by the bank official in the form of bribes received from the debtors in order to grant credit. Corruption by banks official can have both negative and positive impact on bank lending. The negative impact on bank lending is through the increase in the amount demanded by officials for allocating credit. This is a cost to debtors and can reduce borrowing. The positive impact is that corruption can also stimulate the growth of credit. The bribes by the debtors to the bank officials increase their chances of obtaining loan. In addition, the incentive to offer bribes increases for the borrower when banks are more risk averse and more loan applications are rejected. Stiglitz and Weiss (1981) show that adverse selection, resulting from ex ante information asymmetry between the bank and the borrower, causes credit rationing. The existence of credit rationing suggests that some borrowers may be willing to pay more than the official loan rate to obtain credit. As a consequence, borrowers have an incentive to bribe bank officials to obtain the loan. A strong legal environment and banking competition however reduce the likelihood of corruption in bank lending. Barth et al. (2009) find evidence that banking competition and information sharing reduce lending corruption. The ownership structure of the firms and the banks and the legal environment significantly impacts on lending corruption.

\section{Conclusions}

SMEs are expected to be an important vehicle to address the challenges of job creation, sustainable economic growth, equitable distribution of income and the overall stimulation of economic development. The survival rate of SMEs is relatively low and this is a global phenomenon. It is estimated that the failure rate SMEs is between 70 per cent and 80 per cent in South Africa. Access to debt finance represents one of the most significant challenges for SMEs. Access to debt finance to by SMEs can be influenced by both borrower-specific (internal factors) and systemic factors (external factors). The study focused on four external factors. These were the macro environment, the legal system, crime and corruption. The study finds that macro-economic conditions affect small business finance. Banks need to acquire costly information on borrowers before extending loans to new or existing customers, uncertainty about economic conditions (and the likelihood of loan default) would have clear effects on their lending strategies. In addition, an inefficient legal environment which can be shown by the long procedures, duration and cost it takes to register property, enforce contracts and close business upon bankruptcy may affect the availability of debt finance to SMEs. Crime may affect the capacity of new SMEs to repay credit granted. This may affect the willingness of banks and other creditors to extend credit to SMEs especially those that are located in high crime areas. Corruption by banks official can negatively impact on bank lending through the increase in the amount demanded by officials for allocating credit. The incentives to offer bribes increases for the borrower when banks are more risk averse and more loan applications are rejected. A strong legal environment and banking competition however reduce the likelihood of corruption in bank lending. The external environment is largely uncontrollable by the firms. Therefore, government has a large role to play in improving the external environment. Government needs to take crime reduction more seriously through better policing, education and poverty reduction measures. The legal system must be made more efficient. The speed of court judgment must be enhanced. Public awareness campaigns are necessary to change the mindsets of the public that unethical behaviours and corruption are bad and counterproductive. Strong fiscal and monetary policies must be sustained. A limitation of the study is that not all the factors in the external environment (such as the regulatory environment) were considered. 


\section{References}

Ahmad, F. (2013). Corruption and Information Sharing as Determinants of Non-Performing Loans. Business Systems Research, 4(1): 87-98.

Asian Development Bank-Organisation for Economic Cooperation and Development (2014), ADB-OECD Study on Enhancing Financial Accessibility for SMEs: Lessons from Recent Crises. [Online] Available: http://www.adb.org/publications/adb-oecd-studyenhancing-financial-accessibility-smes-lessons-recent-crises (June 10, 2014)

Athanasouli, D., Goujard, A., Sklias, P (2012). Corruption and Firm Performance: Evidence from Greek Firms. International Journal of Economic Sciences and Applied Research, 5(2): 43-67.

Barbosa, Evaldo, Moraes, Cristiana (2004), Determinants of the firm's capital structure: The case of the very small enterprises. [On-line]. Available: http://econpa.wustl.edu.8089/eps/fin/papers 0302/0302001.pdf (August 18, 2013)

Barth, J. R., Lin, C., Lin, P., Song, F. M. (2009). Corruption in bank lending to firms: Cross-country micro evidence on the beneficial role of competition and information sharing. Journal of Financial Economics, 91(3): 361-388.

Barrios, Antonio, (2013), Understand the Five C's of Credit Analysis. [Online] Available: http://sbdc.kennesaw.edul 5CsofCreditAnalysis.htm (June 5, 2014)

Baum, C.F., Caglavan, M. (2008). The Impact of Macroeconomic Uncertainty on the Allocation of Loanable Funds. Journal of Financial Economics, 4(3): 72-91.

Beck, T. (2007). Financing constraints of SMEs in developing countries: evidence, determinants and solutions. Journal of International Money and Finance, 31(2): 401-441.

Blumberg, B.F., Letterie, W.A. (2008). Business starters and credit rationing in small business. Small Business Economics, 3(1): 187200.

Cant, M., Wiid, J. (2013). Establishing The Challenges Affecting South African SMEs. International Business \& Economics Research Journal, 12(6):707-715

Carbó-Valverde, Santiago, Rodríguez-Fernández, Francisco, Udell, Gregory, (2012), Trade credit, the financial crisis, and firm access to finance. [On-line]. Available: http://www.centralbank.ie/stability/documents/sme\%20conference/session\%202/paper.pdf (June 5, 2014)

Chodokufa, Kudakwashe (2009). An analysis of the business relationship between SMEs and insurance companies in the Nelson Mandela Metropolitan area. [On-line]. Available: http://ufh.netd.ac.za/bitstream/10353/279/1/Kudakwashe_Chodokufa_ Dissertation.pdf (May 5, 2014)

Correia, C., Flynn, D., Uliana, E., Wormald, M. (2011). Financial Management (7th ed.). Cape Town: Juta

Cosh, A., Cumming, D., Hughes, A. (2009). Outside Entrepreneurial Capital. Economic Journal, 119(540): 1494-1533.

Demirguc-Kunt, A., Maksimovic, V., Beck, T., Laeven, L. (2006). The determinant of financing obstacles. International Journal of Money and Finance, 25(6): 932-952

Demombynes, G., Ozler, B. (2005). Crime and legal inequality in South Africa. Journal of Development Economics, 76(2): $265-292$.

Djankov, S., McCleish, C., Shleifer, A. (2007). Private credit in 129 countries. Journal of Financial Economics, 84(2): 299-329.

Ehlers, T., Lazenby, K. (2011). Strategic management. South Africa concepts and cases. (3 $3^{\text {rd }}$ ed.). Pretoria: Van Schaik.

Fatoki O., Garwe, D. (2010). Obstacles to the growth of new SMEs in South Africa: A

Principal component analysis approach. African Journal of Business Management 4(5): 729-738

FinScope (2010), South Africa small business survey [Online] Available: http://www.btrust.org.za/downloads/0_nsbs_finscope_small_ business_survey_final_report_march_2011.pdf (June 5, 2014)

Grant Thornton Survey. 2007 . Crime in South Africa. [Online]. Available: http://www.gt.co.za/index/asp (November 18, 2013)

Haron, H., Said, S.B., Jayaraman, K., Ismail, I. (2013). Factors Influencing Small Medium Enterprises in Obtaining Loan. International Journal of Business and Social Science 4(15):182-195

Herrington, Mike, Kew, Jacqui, Kew, Penny (2009), Global Entrepreneurship Monitor, South African report. [Online]. Available: http://www.gbs.nct.ac.za/gbswebb/userfiles/gemsouthafrica2000pdf (October 16, 2013)

Isaacs, E., Friedrick, C. (2007). Crime and HIVIAIDS in the Western Cape. Business support organisation and business owners' perception. African Journal of Business Management, 1(1): 8-18.

Kimuyu, P (2007). Corruption, firm growth and export propensity in Kenya. International Journal of Social Economics, $34(3)$ : 197 - 217

La Porta, R., Lopez-de-Silanes, F., Shleifer, A., Vishny, R. (1997). Legal determinant of external finance. Journal of finance, 52(3): 11311150 .

La Porta, R., Lopez-de-Silanes, F., Shleifer, A., Vishny, R. (1998). Law and finance. Journal of Political Economy, 106(6): 1113-1155.

Lee, Neil, Sameen, Hiba, Martin, Lloyd, (2013). Credit and the crisis Access to finance for innovative small firms since the recession. [Online].Available:http://www.biginnovationcentre.com/Assets/Docs/Reports/SME\%20Finance\%20BIC\%20version\%20 FINAL.pdf (May 15, 2014)

Linden, L.L., Rockoff, J.E. (2008). Estimates of the Impact of Crime Risk on Property Values from Megan's Laws. American Economic Review, 98(3): 1103-1127

Modigliani, F., Miller, M.H. (1958). The cost of capital, corporation finance and the theory of investment. American Economic Review, 48(3):261-295.

Mutezo, Ashly, (2005), Obstacles in the access to SMME finance: an empirical perspective on Tshwane. [Online]. Available: http://uir.unisa.ac.za/bitstream/handle/10500/1803/?sequence=1 (May 5, 2013) 
Organisation for Economic Cooperation and Development (2013), Economic survey South Africa. [Online]. Available: http://www.oecd.org/eco/surveys/South\%20Africa\%202013\%200verview\%20FINAL.pdf (May 3, 2014)

Organisation for Economic Co-operation and Development (2014). Financing SMEs and Entrepreneurs (2014). An OECD Scoreboard. [Online] Available: http://www.oecd.org/industry/smes/ (May 28, 2014)

Rogerson, C.M. (2008). Tracking SMME development in South Africa: issues of finance, training and regulatory environment. Urban Forum, 19, 61-81.

Scheers, $L$ (2010). Challenges of small family groceries shops in South Africa. World Journal of Entrepreneurship, Management and Sustainable Development, 6(3): 221 - 231

Schwienbacher, Armin, Larralde, Benjamin (2010), Crowdfunding of small entrepreneurial ventures [Online] Available: http://www.ema.eu/fileadmin/content/REALISE_IT_2/REALISE_IT_3/CROWD_OUP_Final_Version.pdf (June 5, 2014)

South African Police Service (2014), Crime Statistics Overview RSA $\bar{A}$ 2012/2013. [Online] Available:http://www.saps.gov.za/ resource_centre/publications/statistics/crimestats/2013/crime_stats.php (June 5, 2014)

Standard and Poor's. (2007), Debt recovery for creditors and the law of insolvency in South Africa. [Online]. Available: http://www.standardandpoor.com/spf/pdf/events/blr200713.pdf (November 15, 2012)

Standard Bank \& Fujistu Siemens Computers. (2009) SME survey 2008. [Online]. Available: http://www.smesurvey.co.za/content (May $2,2013)$

Statistics South Africa (2014), Quarterly Labour Force Survey From [Online] Available: http://www.statssa.gov.za/publication/find publication asp (May 29, 2014).

Stiglitz, J., Weiss, A. (1981). Credit rationing in markets with imperfect information. American Economic Review, 71(3): $393-410$.

United Nations Industrial Development Organisation. (2007), Corruption prevention to foster SME development. [Online]. Available: http://www.unido.org/index.php?id=5651 (April 13, 2013)

United Nations Office on Drugs and Crime (2013), Global Study on homicide. [Online] Available: http://www.unodc.org/742DE067-471A459E-9152- (May 10, 2014)

Wall Street Journal (2014). Shrinking Economy Challenges South Africa's New Government. [Online] Available: http://online.wsj.com Inews/articles (June 12, 2014)

Wehinger, Gert. (2014), SMEs and the credit crunch: Current financing difficulties, policy measures and a review of literature. [Online] Available: http://www.oecd.org/finance/SMEs-Credit-Crunch-Financing-Difficulties.pdf (June 5, 2014)

Weill. L. (2011). Does Corruption Hamper Bank Lending; Macro and Micro Evidence. Empirical Economics 41(1): 25-42 